\title{
KETERSEDIAAN PANGAN KEDELAI (Glicine max) \\ DI KABUPATEN PATI
}

\section{SOYBEAN FOODS AVAIBILITY (Glicine max) \\ IN PATI REGENCY}

\author{
Sutrisno \\ Kantor Penelitian dan Pengembangan Kab. Pati \\ email: trisno_1201@yahoo.com
}

Naskah Masuk: 14 Mei $2014 \quad$ Naskah Revisi: 21 Mei $2014 \quad$ Naskah Diterima: 28 Mei 2014

\begin{abstract}
Food sufficiency and nutrition is one of very important factor in determining the quality of human resources. The research aimed to analyze the availability of soybeans in strengthening food security. The research used descriptive method. Data source came from primary data by in-depth interview and observation, while secondary data obtained from the relevant documents. Data analyzed with qualitative and quantitative descriptive. Result of the research showed that soybean availability of Pati Regency in average during last five years (2008, 2009, 2010, 2011, 2012) had a surplus of 2,559 tons of material beyond the need for tempeh and tofu domestic industry, growth trend of soybean production minus 245.3 tons, so it needs an effort to increase soybean production. Meanwhile, soybean average price for 11 months in 2013 amounted to $R p$ 8,861/kg with growth average of $4.42 \%$ and soybean price forecast at month 13 (January 2014) was Rp 11,882/kg.
\end{abstract}

Keywords: avaibility, price, soybean

\begin{abstract}
ABSTRAK
Kecukupan pangan dan gizi merupakan salah satu faktor yang sangat penting dalam menentukan kualitas sumber daya manusia. Penelitian ini bertujuan untuk menganalisis ketersediaan kedelai dalam memperkuat ketahanan pangan. Penelitian ini menggunakan metode deskriptif. Sumber data berasal dari data primer dengan cara wawancara mendalam dan observasi, sedangkan data sekendair diperoleh dari dokumen yang relevan. Data dianalisis dengan metode deskriptif kualitatif dan kuantitatif. Hasil penelitian menunjukkan bahwa ketersediaan kedelai di Kabupaten Pati ratarata lima tahun terakhir (2008, 2009, 2010, 2011, 2012) mengalami surplus sebesar 2.559 ton diluar kebutuhan untuk bahan industri rumah tangga tempe dan tahu, dengan tren (kecenderungan) perkembangan produksi kedelai minus 245,3 ton sehingga perlu upaya meningkatkan produksi kedelai. Sementara itu, harga kedelai rata-rata selama 11 bulan pada tahun 2013 sebesar Rp $8.861 / \mathrm{kg}$ dengan pertumbuhan rata-rata 4,42 \% dan prediksi harga kedelai pada bulan ke-13 (Januari 2014) adalah Rp 11.882/kg.
\end{abstract}

Kata kunci: harga, kedelai, ketersediaan 


\section{PENDAHULUAN}

Kecukupan pangan dan gizi adalah salah satu faktor yang sangat penting dalam menentukan kualitas sumber daya manusia. Di sisi lain, kualitas sumber daya manusia juga sangat menentukan dalam peningkatan produktivitas dan daya saing bangsa dalam era persaingan global seperti saat ini. Oleh karena itu, ketahanan pangan menjadi isu yang sangat strategis dan fundamental dalam perencanaan pembangunan yang berkesinambungan.

Undang-Undang No. 18 Tahun 2012 tentang Pangan menyebutkan bahwa ketahanan pangan adalah kondisi terpenuhinya pangan bagi negara sampai dengan perseorangan yang tercermin dari tersedianya pangan yang cukup, baik jumlah maupun mutunya, aman, beragam, bergizi, merata, dan terjangkau serta tidak bertentangan dengan agama, keyakinan, dan budaya masyarakat untuk dapat hidup sehat, aktif, dan produktif secara berkelanjutan.

Peningkatan jumlah penduduk menjadi salah satu permasalahan pemenuhan kebutuhan pangan terutama kedelai, termasuk di Kabupaten Pati Provinsi Jawa Tengah. Peningkatan jumlah penduduk berkorelasi positif dengan peningkatan pemenuhan kebutuhan pangan. Mengacu pada pertumbuhan penduduk Kabupaten Pati pada 2 (dua) tahun terakhir (2011 dan 2012) masingmasing yaitu 1.198.529 jiwa dan 1.207.399 jiwa dengan pertumbuhan $0,74 \%$ (BPS Kab. Pati, 2011 dan 2012). Jumlah penduduk Kabupaten Pati tahun 2017 diperkirakan akan mencapai 1.247.478 jiwa. Kondisi ini mengindikasikan bahwa kebutuhan terhadap pangan semakin meningkat dari tahun ke tahun. Sementara luas lahan sawah berdasarkan pengairan $59.332 \mathrm{Ha}$, dengan perincian: pengairan teknis $17.887 \mathrm{Ha}$; pengairan setengah teknis $8.900 \mathrm{Ha}$; pengairan sederhana $7.165 \mathrm{Ha}$; pengairan desa $2.758 \mathrm{Ha}$; sawah tadah hujan $22.376 \mathrm{Ha}$; folder dan lainnya 245 Ha (BPS Kab. Pati, 2012).

Kedelai merupakan salah satu komoditas pangan utama setelah padi dan jagung. Komoditas ini memiliki beragam kegunaan, terutama sebagai bahan baku industri makanan kaya protein nabati dan sebagai bahan baku industri pakan ternak. Selain sebagai sumber protein nabati, kedelai merupakan sumber lemak, mineral, dan vitamin serta dapat diolah menjadi berbagai makanan seperti tahu, tempe, tauco, kecap, dan susu.

Untuk mencukupi kebutuhan kedelai, pemerintah melakukan impor. Sementara kebutuhan kedelai Indonesia pada tahun 2010 mencapai 2,79 juta ton (Nasution, 1990). Sedangkan produksi kedelai Jawa Tengah tahun 2012 mencapai 112.273 ton (BPS Prov. Jateng, 2012) dan produksi kedelai Kabupaten Pati 2.763 ton dari luas panen 2.521 Ha (BPS Kab. Pati, 2012).

Untuk mengurangi ketergantungan pada kedelai impor yang terus meningkat, diperlukan upaya yang sungguh-sungguh untuk meningkatkan produksi kedelai dalam negeri, baik melalui perluasan areal tanam, peningkatan produktivitas maupun pemberian dukungan pemerintah melalui kebijakan yang berpihak kepada petani, seperti pengaturan tata niaga kedelai, tarif bea masuk, dan penetapan harga dasar. Diharapkan berbagai kebijakan tersebut dapat memotivasi petani untuk berpartisipasi dalam pengembangan agribisnis kedelai.

Beberapa argumen tentang pentingnya pengembangan kedelai adalah: (1) pertambahan jumlah penduduk, (2) usaha tani kedelai melibatkan lebih dari dua juta rumah tangga petani, (3) peningkatan pendapatan masyarakat dan kesadaran pentingnya mengonsumsi protein nabati, (4) perkembangan industri makanan berbahan baku kedelai, seperti tahu, tempe, kecap, dan tauco, serta (5) perkembangan industri pakan yang salah 
satu komponen utamanya adalah bungkil kedelai. Kondisi tersebut menyebabkan permintaan terhadap kedelai terus meningkat setiap tahun (Zakaria, 2010).

Kondisi geografis dan tingkat kesesuaian lahan pertanian Kabupaten Pati menunjukkan terdapat potensi yang cukup besar untuk pengembangan kedelai sebagai produk pertanian pangan dan sumber ketersediaan pangan nabati, karena pada tahun 1970-an Kabupaten Pati sudah terkenal sebagai daerah penghasil kedelai lokal varitas "petek". Kondisi ini merupakan cerminan bagi Kabupaten Pati Provinsi Jawa Tengah dan daerah lainnya di wilayah Indonesia. Luas lahan dan kesuburan tanah Kabupaten Pati ternyata belum dapat dimanfaatkan secara optimal untuk membangun ketahanan pangan dan perekonomian rakyat pedesaan. Hal inilah yang menarik perhatian penulis untuk meneliti ketersediaan komoditas kedelai untuk menunjang ketahanan pangan di Kabupaten Pati.

\section{TINJAUAN PUSTAKA}

\section{Ketahanan Pangan}

Dari perspektif sejarah istilah ketahanan pangan (food security) muncul dan dibangkitkan karena kejadian krisis pangan dan kelaparan. Istilah ketahanan pangan dalam kebijakan pangan dunia pertama kali digunakan pada tahun 1971 oleh PBB untuk membebaskan dunia terutama negara-negara berkembang dari krisis produksi dan suplai makanan pokok. Fokus ketahanan pangan pada masa itu menitik beratkan pada pemenuhan kebutuhan pokok dan membebaskan daerah dari krisis pangan. Sementara itu menurut PP No. 68 Tahun 2002 menyebutkan bahwa Ketahanan Pangan adalah kondisi terpenuhinya pangan bagi rumah tangga yang tercermin dari tersedianya pangan yang cukup, baik jumlah maupun mutunya, aman, merata dan terjangkau. Sementara, ketersediaan pangan adalah tersedianya pangan dari hasil produksi dalam negeri dan/atau sumber lain.

\section{Kedelai}

Tanaman kedelai (Glicine max) yang berasal dari Cina dan kemudian dikembangkan ke berbagai negara, adalah tanaman semusim yang termasuk family Leguminosae. Keunggulan teknis budidaya yang sederhana telah memungkinkan kedelai dapat dibudidayakan di daerah subtropis dan tropis dengan skala masif. Kandungan gizi kedelai cukup tinggi, terutama proteinnya mencapai $34 \%$, sehingga sangat diminati sebagai sumber protein nabati yang relatif murah dibandingkan dengan protein hewani (Dirjentan, 2004).

Selain sebagai sumber protein nabati, kedelai juga sebagai pangan fungsional untuk mencegah timbulnya penyakit degeneratif, seperti jantung koroner dan hipertensi. Bahkan kandungan zat isoflavon pada kedelai ternyata berfungsi sebagai antioksidan. Perkembangan teknologi terakhir menunjukkan bahwa saat ini kedelai banyak digunakan sebagai sumber energi alternatif (biofuel).

Kedelai merupakan salah satu jenis tanaman yang masih sulit dimanipulasi secara in vitro, karena tanaman ini bersifat rekalsitran. Meskipun telah banyak dilaporkan keberhasilan regenerasi tanaman pada kedelai, ternyata masih sulit diulang oleh peneliti lain (tidak reproducible). Keberhasilan regenerasi tanaman kedelai sangat tergantung pada genotipe yang digunakan (Barwale et al., 1986).

\section{METODE PENELITIAN}

Penelitian ini menggunakan metode deskriptif. Menurut Travers (1978) metode ini bertujuan untuk menggambarkan sifat sesuatu yang tengah berlangsung pada saat 
riset dilakukan dan memeriksa sebabsebab dari suatu gejala tertentu. Disamping itu, penelitian ini juga menggunakan pendekatan explanatory research dengan tujuan untuk menjelaskan hubungan antara dua atau lebih gejala atau variabel (Leedy and Ormrod, 2005). Faktor-faktor yang menjadi obyek penelitian meliputi ketersediaan, kebutuhan, pertumbuhan, harga, prediksi harga, model rantai pasokan dan pemasaran kedelai di Kabupaten Pati.

Sumber data berupa data primer dan data sekunder. Data primer diperoleh dari observasi/pengamatan dan wawancara dengan para narasumber (petani kedelai, etugas Dispertanak, pedagang), adapun data sekunder diperoleh dari dokumen yang relevan. Analisis deskriptif digunakan untuk menggambarkan kondisi komoditas kedelai di Kabupaten Pati. Analisis regresi digunakan untuk mengetahui perkembangan, kebutuhan/permintaan, tren dan prediksi harga komoditas kedelai di Kabupaten Pati.

\section{HASIL DAN PEMBAHASAN}

Pertumbuhan ekonomi Kabupaten Pati pada tahun 2011 sebesar 5,43\%. Artinya pergerakan ekonomi cenderung naik dibandingkan tahun sebelumnya (2010) yaitu $5,11 \%$. Hal ini tidak terlepas dari peran sektor pertanian yang sangat dominan.

Pertumbuhan sektor pertanian ternyata mengalami pertumbuhan yang melambat dibandingkan tahun sebelumnya. Tiga sektor ekonomi yaitu sektor pertanian, sektor perdagangan, hotel, restoran dan sektor industri pengolahan masih memegang peranan penting dalam perekonomian karena mempunyai sumbangan cukup besar terhadap total PDRB. Peranan sektorsektor tersebut pada tahun 2012 masing- masing sebesar 35,92\%; 19,05\% dan $17,43 \%$. Sementara untuk peranan sektor lain besarannya masih dibawah $10 \%$.

Pertumbuhan pendapatan regional atas dasar harga berlaku dan konstan terlihat bahwa pada tahun 2012 pendapatan per kapita penduduk Kabupaten Pati atas dasar harga berlaku mencapai Rp9.671.214 lebih tinggi dari tahun sebelumnya (2011) yaitu Rp8.767.321. Sedangkan atas dasar harga konstan tahun 2012 tercatat sebesar Rp4.288.499 dan pada tahun 2011 pendapatan per kapita Kabupaten Pati tercatat sebesar Rp4.048.693 (BPS Kab. Pati, 2013).

\section{Komoditas Kedelai}

Pertanian pangan di Kabupaten Pati yang termasuk dalam pertanian pangan nabati unggulan adalah tanaman kedelai. Luas panen kedelai rata-rata 5 tahun terakhir disajikan pada Tabel 1 .

Data pada Tabel 1 menunjukkan bahwa luas panen kedelai terjadi fluktuatif dan tersebar di 8 (delapan) kecamatan potensi tanaman kedelai. Luas panen kedelai rata-rata 5 tahun terakhir mencapai $2.792 \mathrm{Ha}$ dengan pertumbuhan rata-rata minus $1,36 \%$. Luas panen kedelai ini akan mempengaruhi produksi kedelai di Kabupaten Pati.

Luas panen kedelai paling luas dicapai pada tahun 2009 yaitu 3.213 Ha. Hal ini diduga kondisi iklim pada saat itu cukup kondusif dan serangan hama/penyakit tanaman kedelai relatif dapat dikendalikan, sehingga luas panen kedelai lebih luas jika dibanding dengan luas panen kedelai di tahun yang lain.

Luas panen kedelai paling sedikit terjadi pada tahun 2012 yaitu $2.521 \mathrm{Ha}$. Hal ini terjadi karena pengaruh iklim kering yang cukup mengganggu serta terjadinya serangan hama termasuk tikus dan penyakit tanaman sehingga wajar jika terjadi penurunan luas panen kedelai. 


\section{Tabel 1.}

Luas Panen Kedelai di Kabupaten Pati

\begin{tabular}{|c|c|c|c|c|c|c|c|c|}
\hline \multirow{2}{*}{ Kecamatan } & \multicolumn{5}{|c|}{ Luas Panen Kedelai } & \multirow{2}{*}{$\begin{array}{c}\text { Jumlah } \\
\text { (Ha) }\end{array}$} & \multirow{2}{*}{$\begin{array}{c}\text { Rata-rata } \\
\text { (Ha) }\end{array}$} & \multirow{2}{*}{$\begin{array}{c}\text { Pertumbuhan } \\
(\%)\end{array}$} \\
\hline & 2008 & 2009 & 2010 & 2011 & 2012 & & & \\
\hline Sukolilo & 71 & 217 & 157 & 158 & 231 & 834 & 167 & 56,21 \\
\hline Kayen & 1.178 & 890 & 832 & 821 & 727 & 4.448 & 890 & $-10,93$ \\
\hline Tambakromo & 110 & 123 & 106 & 150 & 134 & 623 & 125 & 7,21 \\
\hline Winong & 241 & 341 & 361 & 312 & 333 & 1.588 & 318 & 10,13 \\
\hline Pucakwangi & 63 & 78 & 58 & 0 & 10 & 209 & 42 & - \\
\hline Jaken & 9 & 43 & 51 & 0 & 52 & 155 & 31 & - \\
\hline Batangan & 0 & 0 & 0 & 0 & & 0 & 0 & - \\
\hline Juwana & 0 & 0 & 0 & 0 & & 0 & 0 & - \\
\hline Jakenan & 72 & 147 & 123 & 138 & 58 & 538 & 108 & 10,52 \\
\hline Pati & 333 & 476 & 468 & 362 & 68 & 1.707 & 341 & $-15,65$ \\
\hline Gabus & 429 & 616 & 292 & 585 & 653 & 2.575 & 515 & 25,74 \\
\hline Margorejo & 156 & 210 & 221 & 246 & 256 & 1.089 & 218 & 13,81 \\
\hline Gembong & 0 & 0 & 0 & 0 & & 0 & 0 &  \\
\hline Tlogowungu & 0 & 14 & 0 & 0 & & 14 & 3 & 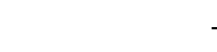 \\
\hline Wedarijaksa & 95 & 26 & 1 & 0 & & 122 & 24 & 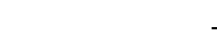 \\
\hline Trangkil & 0 & 12 & 0 & 0 & & 12 & 2 & 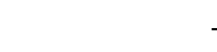 \\
\hline Margoyoso & 0 & 0 & 0 & 0 & & 0 & 0 & 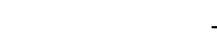 \\
\hline Gn. wungkal & 0 & 0 & 0 & 0 & & 0 & 0 & . \\
\hline Cluwak & 0 & 0 & 0 & 0 & & 0 & 0 & 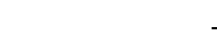 \\
\hline Tayu & 0 & 20 & 0 & 29 & 54 & 103 & 21 & - \\
\hline Dukuhseti & 0 & 0 & 0 & 0 & & 0 & 0 & 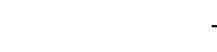 \\
\hline Jumlah & 2.757 & 3.213 & 2.670 & 2.800 & 2.521 & 13.961 & 2.792 & $-1,36$ \\
\hline
\end{tabular}

Sumber: BPS Kab. Pati (2008, 2009, 2010, 2011, 2012).

Produksi kedelai rata-rata 5 tahun terakhir di Kabupaten Pati secara rinci dapat dilihat pada Tabel 2 .

Data tersebut menunjukkan bahwa produksi kedelai terjadi secara fluktuatif dan tersebar di 8 kecamatan yang potensial untuk tanaman kedelai. Rata-rata produksi kedelai dalam 5 tahun terakhir mencapai 2.622 ton dengan pertumbuhan rata-rata 23,75\%.

Produksi kedelai paling tinggi terjadi pada tahun 2009 yaitu 4.600 ton. Hal ini paralel dengan luas panen kedelai pada tahun 2009. Produksi tinggi ini diduga karena kondisi iklim pada saat itu cukup kondusif, teknologi budidayanya cukup baik dan serangan hama/penyakit tanaman kedelai relatif dapat dikendalikan, sehingga produksi kedelai paling tinggi jika dibanding dengan produksi kedelai pada tahun-tahun yang lain.

Produksi kedelai paling rendah dicapai pada tahun 2011 yaitu 1.501 ton dengan luas panen $2.800 \mathrm{Ha}$. Sementara luas panen paling rendah dicapai pada tahun 2012 yaitu dengan luas lahan 2.521 Ha. Hal ini terjadi karena pengaruh iklim ekstrim yang cukup mengganggu 
produktivitas kedelai. Selain itu, serangan hama tikus dan penyakit tanaman juga mengganggu produktivitas kedelai. Hal-hal seperti inilah yang berpengaruh terhadap penurunan produksi kedelai pada tahun 2011.

Tabel 2.

Produksi Kedelai

\begin{tabular}{|c|c|c|c|c|c|c|c|c|}
\hline \multirow{2}{*}{ Kecamatan } & \multicolumn{5}{|c|}{ Produksi (Ton) } & \multirow{2}{*}{$\begin{array}{c}\text { Jumlah } \\
\text { (Ton) } \\
\end{array}$} & \multirow{2}{*}{$\begin{array}{c}\text { Rata-rata } \\
\text { (Ton) }\end{array}$} & \multirow{2}{*}{$\begin{array}{c}\text { Pertumbuhan } \\
(\%)\end{array}$} \\
\hline & 2008 & 2009 & 2010 & 2011 & 2012 & & & \\
\hline Sukolilo & 101 & 309 & 122 & 88 & 253 & 873 & 175 & 76,17 \\
\hline Kayen & 167 & 1.265 & 500 & 468 & 797 & 3.197 & 639 & 165,22 \\
\hline Tambakromo & 156 & 174 & 69 & 60 & 147 & 606 & 121 & 20,99 \\
\hline Winong & 343 & 485 & 192 & 203 & 365 & 1.587 & 317 & 16,66 \\
\hline Pucakwangi & 92 & 114 & 434 & 0 & 11 & 261 & 52 & - \\
\hline Jaken & 13 & 62 & 24 & 0 & 57 & 156 & 31 & - \\
\hline Batangan & 0 & 0 & 0 & 0 & 0 & 0 & 0 & - \\
\hline Juwana & 0 & 0 & 0 & 0 & 0 & 0 & 0 & - \\
\hline Jakenan & 99 & 202 & 83 & 69 & 64 & 516 & 103 & 5,14 \\
\hline Pati & 459 & 656 & 267 & 263 & 74 & 1.720 & 344 & $-22,41$ \\
\hline Gabus & 636 & 914 & 346 & 164 & 716 & 2.776 & 555 & 66,27 \\
\hline Margorejo & 233 & 314 & 118 & 124 & 281 & 1.070 & 214 & 25,87 \\
\hline Gembong & 0 & 0 & 0 & 0 & 0 & 0 & 0 & - \\
\hline Tlogowungu & 0 & 19 & 0 & 0 & 0 & 19 & 3.8 & - \\
\hline Wedarijaksa & 141 & 39 & 15 & 0 & 0 & 195 & 39 & - \\
\hline Trangkil & 0 & 17 & 0 & 0 & 0 & 17 & 3 & - \\
\hline Margoyoso & 0 & 0 & 0 & 0 & 0 & 0 & 0 & - \\
\hline Gn.wungkal & 0 & 0 & 0 & 0 & 0 & 0 & 0 & - \\
\hline Cluwak & 0 & 0 & 0 & 0 & 0 & 0 & 0 & - \\
\hline Tayu & 0 & 30 & 0 & 0 & 59 & 89 & 18 & - \\
\hline Dukuhseti & 0 & 0 & 0 & 0 & 0 & 0 & 0 & - \\
\hline Jumlah & 2.440 & 4.600 & 1.806 & 1.501 & 2.763 & 13.110 & 2.622 & 23,75 \\
\hline
\end{tabular}

Sumber: BPS Kab. Pati $(2008,2009,2010,2011,2012)$.

\section{Ketersediaan Kedelai}

Ketersediaan

dan

tren perkembangan produksi kedelai selama 5 tahun terakhir dapat dilihat pada Tabel 3.

Tabel 3 menunjukkan bahwa ketersediaan kedelai rata-rata 5 tahun terakhir di Kabupaten Pati mengalami surplus 2.559 ton. Sementara tahun 2012 juga mengalami surplus sebesar 2.700 ton.
Surplus kedelai ini diduga distribusikan untuk industri tahu-tempe dan kebutuhan lain yang relevan dengan komoditas kedelai, hanya saja belum tersaji datanya.

Tren produksi kedelai Kabupaten Pati selama 5 tahun terakhir (2008-2012) menunjukkan angka negatif 245,3 yang artinya produksi kedelai mengalami kecenderungan menurun sebesar 245,3 ton. 


\section{Tabel 3.}

Ketersediaan Kedelai

\begin{tabular}{ccrrr}
\hline Tahun & $\begin{array}{c}\text { Produksi } \\
\text { (ton) }\end{array}$ & Penduduk & $\begin{array}{c}\text { Kebutuhan (ton) } \\
\mathbf{0 . 0 5 2} \text { kg/kapita/th*) }\end{array}$ & $\begin{array}{c}\text { Keterangan } \\
(+/-)\end{array}$ \\
\hline 2008 & 2.440 & 1.256 .182 & 65,32 & 2.375 \\
2009 & 4.600 & 1.190 .993 & 61,93 & 4.538 \\
2010 & 1.806 & 1.194 .501 & 62,11 & 1.744 \\
2011 & 1.501 & 1.198 .529 & 62,32 & 1.439 \\
2012 & 2.763 & 1.207 .399 & 62,78 & 2.700 \\
Jumlah & $\mathbf{1 3 . 1 1 0}$ & $\mathbf{6 . 0 4 7 . 6 0 4}$ & $\mathbf{3 1 4 , 4 7}$ & $\mathbf{1 2 . 7 9 6}$ \\
Rata-rata & $\mathbf{2 . 6 2 2}$ & $\mathbf{1 . 2 0 9 . 5 2 1}$ & $\mathbf{6 2 , 8 9}$ & $\mathbf{2 . 5 5 9}$ \\
Coefficient & $\mathbf{Y = 4 9 5 6 7 5 . 0 0 0}$ & & \\
Tren & $\mathbf{- 2 4 5 , 3}$ & & & \\
\hline \multicolumn{5}{l}{ Sumber: Pengolahan Data (2013), *) BPS RI (2012). }
\end{tabular}

\section{Pertumbuhan Harga Kedelai}

Tren harga kedelai menunjukkan peningkatan harga tiap bulannya.
Pertumbuhan harga kedelai selama pengamatan 11 bulan pada tahun 2013 dapat dilihat pada Tabel 4.

Tabel 4.

Pertumbuhan Harga Kedelai

\begin{tabular}{lrr}
\hline \multicolumn{1}{c}{ Bulan } & $\begin{array}{c}\text { Harga } \\
(\mathbf{R p} / \mathbf{k g})\end{array}$ & $\begin{array}{r}\text { Pertumbuhan } \\
(\mathbf{\%})\end{array}$ \\
\hline Januari & 7.200 & \\
Februari & 7.100 & $-1,39$ \\
Maret & 7.650 & 7,746 \\
April & 7.650 & 0 \\
Mei & 8.075 & 5,55 \\
Juni & 8.575 & 6,19 \\
Juli & 9.125 & 6,41 \\
Agustus & 9.925 & 8,77 \\
September & 10.425 & 5,04 \\
Oktober & 10.700 & 2,64 \\
Nopember & 11.050 & 3,27 \\
Jumlah & $\mathbf{9 7 . 4 7 5}$ & $\mathbf{4 , 4 2}$ \\
Rata-rata & $\mathbf{8 . 8 6 1}$ & \\
Coefficients & Y= 6266+432 (13) = 11882 \\
R Square & $\mathbf{0 , 9 6 5}$ & \\
\hline Sumber: Pengolahan Data Pasar Porda Juwana (2013).
\end{tabular}


Tabel 4 menunjukkan bahwa harga kedelai rata-rata selama 11 bulan pada tahun 2013 sebesar Rp8.861/kg, dengan pertumbuhan 4,42\%. Harga kedelai tertinggi berada di bulan Nopember yaitu Rp11.050/kg dengan pertumbuhan 3,27\%, hal ini terjadi karena pada bulan tersebut persediaan kedelai menipis karena belum masa panen, sehingga wajar jika harga naik jika dibanding dengan bulan-bulan lainnya. Sedangkan harga terendah berada di bulan Februari yaitu Rp $7.100 / \mathrm{kg}$, dengan pertumbuhan minus $1,39 \%$, hal ini terjadi karena pada bulan tersebut persediaan kedelai sudah lebih dari cukup karena terjadi masa panen kedelai.

Prediksi harga kedelai pada bulan ke 13 (Januari 2014) adalah Rp 11.882/kg, dengan R Square adalah 0,965. Angka ini menjelaskan bahwa 96,5\% keragaan data dalam harga kedelai dijelaskan oleh persamaan regresi tersebut.

\section{KESIMPULAN DAN SARAN}

\section{Kesimpulan}

Ketersediaan pangan kedelai di Kabupaten Pati rata-rata lima tahun terakhir (2008, 2009, 2010, 2011, 2012) mengalami surplus sebesar 2.559 ton diluar kebutuhan untuk industri tahutempe dan kebutuhan lain yang relevan dengan kedelai dengan tren (kecenderungan) perkembangan produksi kedelai minus 245,3 ton. Sementara harga kedelai rata-rata selama 11 bulan pada tahun 2013 sebesar Rp8.861/kg dengan pertumbuhan rata-rata $4,42 \%$ dan prediksi harga kedelai pada bulan ke-13 (Januari 2014) adalah Rp11.882/kg.

\section{Saran}

Kebutuhan kedelai untuk industri tahu-tempe dan kebutuhan lain yang relevan dengan kedelai masih belum tercukupi, ketersediaan kedelai untuk konsumsi masyarakat sudah tercapai dan mengalami surplus. Surplus kedelai tersebut kemudian disalurkan ke industri tahu-tempe dan kebutuhan lain yang relevan dengan kedelai, walaupun masih kurang. Untuk mencukupi kebutuhan industri tahu-tempe dan kebutuhan lain yang relevan dengan kedelai, disamping mendatangkan dari luar daerah bahkan impor, perlu juga disuplai dari produksi kedelai lokal sendiri. Oleh sebab itu pemerintah daerah Kabupaten Pati perlu mengupayakan peningkatan produksi kedelai baik kuantitas maupun kualitas dengan cara perluasan tanam, penggunaan benih unggul, kemudahan mendapatkan saprodi (sarana produksi), penanganan pasca panen dan peningkatan teknologi budidaya melalui penyuluhan.

\section{UCAPAN TERIMA KASIH}

Ucapan terimakasih disampaikan kepada Sdr. Arieyanti Dwi Astuti, ST yang telah membantu pengumpulan data dalam penelitian ini.

\section{DAFTAR PUSTAKA}

Badan Pusat Statistik Kabupaten Pati. 2008. Pati dalam Angka Tahun 2007. Pati.

2009. Pati dalam Angka Tahun 2008. Pati.

2010. Pati dalam Angka Tahun 2009. Pati.

2011. Pati dalam Angka Tahun 2010. Pati.

2012. Pati dalam Angka Tahun 2011. Pati.

2013. Pati dalam Angka Tahun 2012. Pati.

Badan Pusat Statistik Provinsi Jawa Tengah. 2012. Jawa Tengah Dalam Angka 2011. Semarang. 
Badan Pusat Statistik Republik Indonesia. 2012. Publikasi Konsumsi Rata-rata per Kapita Setahun Beberapa Bahan Makanan di Indonesia 20082012. Jakarta.

Barwale, U. B., H. R. Kerns. and J. M. Widholm. 1986. Plant Regeneration from Callus Cultures of Several Soybean Genotypes via Embryogenesis and Organogenesis. Planta 167: 473- 481.

Direktorat Jenderal Tanaman Pangan. 2004. Profil Kedelai (Edisi 1). Direktorat Kacang-Kacangan dan Umbi-Umbian. Jakarta : Kementerian Pertanian.

Nasution, L. T. 1990. Faktor Pendukung Eksternal Program Benih Kedelai. Risalah Lokakarya Pengembangan Kedelai. Bogor : Pusat Penelitian dan Pengembangan Tanaman Pangan.

Leedy, P. D and J. E. Ormrod. 2005. Practical Research : Planning and Design Research ( ${ }^{\text {th }}$ ed). Ohio : Pearson Merrill Prentice Hall.
Peraturan Pemerintah Republik Indonesia Nomor 68 Tahun 2002 tentang Ketahanan Pangan.

Travers. 1973. Second Handbook of Research on Teaching. Chicago : Rand Mc. Nelly College Publishing Company.

Undang-Undang Republik Indonesia Nomor 18 Tahun 2012 tentang Pangan.

Zakaria, A. K. 2010. Program Pengembangan Agribisnis Kedelai dalam Peningkatan Produksi dan Pendapatan Petani. Bogor : Pusat Analisis Sosial Ekonomi dan Kebijakan Pertanian.

\section{BIODATA PENULIS}

H. Sutrisno, lahir 12 Januari 1956 di kota Kudus propinsi Jawa Tengah. Pendidikan Magister Manajemen dari Universitas Muhamadiyah Surakarta. Saat ini menjadi Peneliti Madya di Kantor Penelitian dan Pengembangan Kabupaten Pati. 